\title{
SEJARAH DAN FILSAFAT SAINS SEBAGAI PENDEKATAN DALAM PENGAJARAN FISIKA PADA KONSEP ARCHIMEDES
}

\author{
Arini Rosa Sinensis ${ }^{1 *}$ \\ ${ }^{1}$ Prodi Pendidikan Fisika STKIP Nurul Huda \\ Jl.Kotabaru Sukaraja, Buay Madang, Kab. Oku Timur \\ *E-mail: arini@stkipnurulhuda.ac.id
}

\begin{abstract}
Abstrak
Artikel ini mengeksplorasi hubungan antara Sejarah dan Filsafat sains dalam menjelaskan konsep hukum archimedes dalam pengajaran fisika. Melalui pengajaran sejarah fisika seorang pendidik dapat memberikan informasi bagaimana suatu konsep fisika ditemukan, melalui sejarah fisika juga dapat menjadi pembelajaran untuk menjadi ilmuan, karena pengetahuan berdasarkan pengalaman ilmuan fisika. Sejarah fisika dan filsafat sains saling berkaitan yaitu filsafat dapat dipahami dengan sungguh-sungguh jika refleksi tentang sejarah ilmu pengetahuan telah dipahami sebelumya. Tinjauan filsafat sains berdasarkan pada ontologi, epistemologi dan aksiologi sebagai landasan pengembangan ilmu dalam pendidikan fisika dapat memberikan kontribusi yang positif dalam mengajarkan fisika. Selain itu dengan pemahaman filsafat sains dapat menumbuhkan interaksi sosial peserta didik untuk memecahkan masalah-masalah yang dihadapi.
\end{abstract}

Kata kunci: Sejarah fisika, Filsafat sains, Pengajaran Fisika

\section{PENDAHULUAN}

Filsafat ilmu pegetahuan memiliki perbedaan dengan sejarah ilmu pengetahuan. Dengan kata lain, filsafat dapat dipahami dengan sungguh-sungguh jika refleksi tentang sejarah ilmu pengetahuan telah dipahami sebelumya. Oleh karena itu, sangatlah penting bagi kita untuk meilihat bagaimana proses perkembangan ilmu pengetahuan dalam konteks historisnya sehingga kita dapat memperoleh pemahaman yang umum dan menyeluruh tentang proses perkembangan ilmu pengetahua tersebut. Penting juga dalam memahami isu-isu utama filsafat dan ilmu pengetahuan. Khususnya, ada isu utama tentang filsafat alam dan bagaimana perkembangan serta perubahannya selama lebih dari 2500 tahun sejarahnya (Wattimena, 2009)

Mengingat pedagogi kaitannya dengan disiplin epistemologi tampaknya mengundang harmonisasi belajar dan mengajar dalam fisika dengan sifat pengetahuan dan proses karakteristik penciptaan pengetahuan dengan tujuan untuk meningkatkan pembelajaran siswa (Sin, 2013). Sebuah survei di Amerika Serikat menemukan bahwa hanya sebagian kecil siswa terlibat dengan pembelajaran aktif atau pemecahan dalam pada masalah dunia nyata dalam sebagian besar kasus, praktek khas adalah dalam penyampaian informasi dari dosen (DeHaan, 2005).

Pendekatan filosofis adalah cara pandang atau paradigma yang bertujuan untuk menjelaskan inti, hakikat, atau hikmah mengenai sesuatu yang berada di balik objek formalnya. Dengan kata lain, pendekatan filosofis adalah upaya sadar yang dilakukan untuk menjelaskan apa dibalik sesuatu yang nampak. Pendekatan filosofis untuk menjelaskan suatu masalah dapat diterapkan dalam aspek-aspek kehidupan manusia, termasuk dalarn pendidikan. Filsafat tidak hanya melahirkan pengetahuan baru, melainkan juga melahirkan filsafat pendidikan. Filsafat pendidikan adalah filsafat terapan untuk memecahkan masalah-masalah pendidikan yang dihadapi. John Dewey (1964) berpendapat bahwa filsafat merupakan teori umum tentang pendidikan. Filsafat sebagai suatu sistem berpikir akan menjawab persoalan-persoalan pendidikan yang bersifat filosofis dan memerlukan jawaban filosofis pula 
Artikel ini membahas tentang sejarah dan filsafat sains sebagai pendekatan dalam pembelajaran dan pengajaran fisika. Filsafat sains yang dibahas ditinjau dari ontologi, epistemologi dan aksiologi pada konsep archimedes serta penerapannya dalam pengajaran fisika.

\section{PEMBAHASAN}

\section{Menempatkan Konteks Mengajar Fisika}

Dalam hal ini, kajian komprehensif dari kemajuan dalam fisika (Thacker, 2003) mencatat bahwa kurikulum dan kursus telah didesain dengan peningkatan pemahaman konseptual dan keterampilan kognitif yang diperlukan untuk memahami dan menerapkan konsep-konsep fisika, lingkungan pengajaran yang menarik dan situasi (seperti "kehidupan nyata"). Strategi "keterlibatan Interaktif" diklaim lebih efektif daripada metode tradisional dalam meningkatkan pemahamannya siswa pada konsep yang sulit (Hake, 2002). Peningkatan belajar siswa melalui partisipasi dalam demonstrasi kelas sebagai lawan dari pembelajaran pasif (Crouch et al, 2004).

Membangun prinsip - prinsip konstruktivis, untuk memberikan peningkatan kesempatan bagi siswa untuk mendiskusikan sifat dan isi pengetahuan. Setelah pendidikan sains pada akhir abad kedua puluh, konstruktivisme diakui bahwa berarti selama interaksi siswa dengan lingkungan dan menganjurkan pengalaman aktif dengan dunia fisik (Matthews, 1997). Upaya reformasi dalam pedagogi fisika telah dikenal dengan "penelitian pendidikan fisika" didorong oleh kesenjangan yang diidentifikasi antara hasil belajar siswa dan pemahaman konseptual yang sebenarnya. Konten, transmisi pengetahuan dan akuisisi, pemahaman konseptual, pengembangan skill generik, penilaian, pelatihan penelitian, dan sebagainya. Integrasi pertimbangan epistemologis (Filsafat sains) pengajaran fisika, lebih lanjut untuk kesenjangan yang diamati antara proses ilmu pengetahuan dan praktekpraktek konstruktivis sosial. Untuk pemahaman pengembangan konseptual, dan perolehan keterampilan tidak hanya untuk karir ilmiah tetapi juga untuk pembangunan sebagai individu dan warga negara. (Sin,2013).

\section{Kajian Sejarah Fisika Tentang Archimedes}

Archimedes (287-213 BC) adalah salah satu filsuf yunani kuno yang dipandang sebagai ilmuan hebat sebelum munculnya ilmu pengetahuan modern melalui karya Issac Newton. Konon, pada waktu ia mandi menmukan rumus fisika yang telah lama ia pikirkan dan kemudian berteriak, "Eureka, eureka". Archimedes telah menemukan sebuah prinsip, bahwa tingkat kemurnian substasi adalah sama di manapun substansi berada. Setiap penambahan kedalam substansi tersebut akan mengubah berat keseluruhan. Tumpahan air merupakan cara sederhana untuk mengetahui hal tersebut.

Dengan mengetahui sejarah fisika maka sangat memudahkan pendidik dalam mengajar, dan akan membuat pengetahuan peserta didik bertambah bahkan memungkinkan bisa menemukan penemuan-penemuan baru yang bisa memperbaiki penemuan sebelumnya. Karena perkem-bangan konten fisika dari masa kemasa setelah mengikuti kegiatan sejarah fisika maka kita akan mengetahui bahwa konten masing-masing ilmu fisika sangan berkaitan dengan konten lainnya.

\section{Kajian Filsafat pada Konsep Archimedes \\ Dasar Ontologi}

Ontologi adalah analisis tentang objek materi dari ilmu pengetahuan, yaitu hal-hal atau benda-benda empiris. Ontologi membahas tentang hakikat apa yang ingin dikaji (Suriasumantri, 2010). Objek telaah dari hukum archimedes ada dua yaitu objek material dan objek formal. Obyek material adalah sesuatu yang dijadikan sasaran penyelidikan, seperti fluida, dan massa jenis adalah obyek material hukum archimedes. Adapun obyek formalnya merupakan metode untuk memahami obyek material tersebut, seperti pendekatan induktif dan deduktif. Dalam perspektif ini bahwa hukum Archimedes pada prinsipnya memiliki dua obyek substantif (Fakta dan kebenaran)

Objek kajian dalam hukum Archimedes merupakan fakta. Fakta adalah pengamatan yang telah diverifikasi secara empiris. Fakta dalam prosesnya kadang kala dapat menjadi 
sebuah ilmu namun juga sebaliknya. Fakta tidak akan dapat menjadi sebuah ilmu manakala dihasilkan secara random saja. Namun bila dikumpulkan secara sistematis dengan beberapa system serta dilakukan secara sekuensial, maka fakta tersebut mampu melahirkan sebuah hukum atau bahkan ilmu. Fakta atau kenyataan memiliki pengertian yang beragam, bergantung dari sudut pandang filosofis yang melandasinya. Contoh fakta yang dikaji atau dibahas dalam hukum Archimedes adalah seperti tumpahnya air dalam baskom yang penuh ketika dimasukkan suatu benda.

Kebenaran/keadaan benar itu berupa kesesuaian antara arti yang dimaksud oleh sebuah pendapat dengan apa yang sungguh merupakan halnya/faktanya". Menurut teori ini dinyatakan bahwa, kebenaran atau keadaan benar itu berupa kesesuaian [corres-pondence] antara arti yang dimaksud oleh suatu pernyataan dengan apa yang sungguhsungguh terjadi merupakan kenyataan atau faktanya. Kebenaran hukum Archimedes sudah terbukti secara korespondensi, koherensi, performatif, pragmatic, dan proposisi. Hukum Archimedes merupakan suatu kebenaran karena bunyi hukum tersebut/teori Archimedes telah tebukti secara ilmiah dan sesuai dengan keadaan alamiah sutau benda. (Lebe, 2015)

Berikutnya keterhubungan antar objek kajian Archimedes dengan hukum Archimedes itu sendiri adalah : Ketika sebuah benda tercelup seluruhnya atau sebagian di dalam zat cair, zat cair akan memberikan gaya ke atas (gaya apung) pada benda, di mana besarnya gaya ke atas (gaya apung) sama dengan berat zat cair yang dipindahkan.

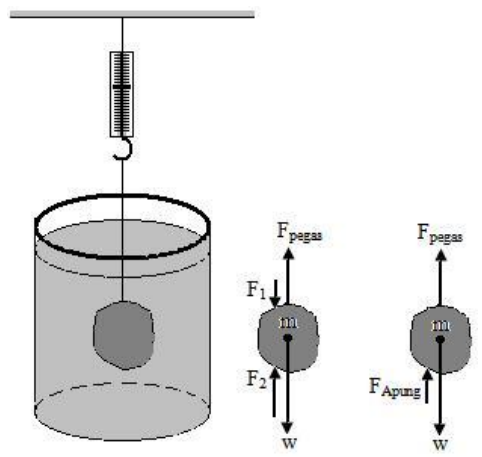

Gambar 1. Penjelasan Hukum Archimedes

$$
\overrightarrow{F_{a}}=\rho g V
$$

dengan: $\overrightarrow{F_{a}}$ (gaya tekan), $\rho$ (massa jenis air), $V=$ Volume air, $g=$ gravitasi bumi

\section{Dasar Epistemologi}

\section{Epistemologi dalam Pengajaran fisika}

Pengajaran tentang epistemologi ilmu mendapatkan penekanan meningkat dalam kurikulum sekolah (AAAS, 1995; Matthews, 1994). Namun, penelitian berbasis kelas telah menunjukkan bahwa saat ini tidak ada secara luas didirikan pengetahuan profesional dan keahlian dalam pengajaran berkaitan dengan mengajar tentang epistemologi ilmu pengetahuan). Sangat mungkin bahwa guru sains menanggapi meningkatnya penekanan pada isu-isu epistemik dalam kurikulum akan sangat bergantung pada sumber daya. Epistemologi diperlukan dalam kurikulum pengajaran fisika antara lain dalam hubungannya Pengetahuan apa yang harus diberikan dan bagaimana cara memperoleh pengetahuan dan cara menyempaikannya seperti apa? Semua itu adalah epistemologinya pendidikan. Epistemologi ditandai dengan perilaku di mana siswa mencoba untuk mencari tahu fenomena tentang dunia fisik. Perilaku yang terkait dengan akal termasuk membuat koneksi ke dunia nyata atau pengalaman hidup, koordinasi beberapa representasi, mengingat solusi, dan menyelesaikan masalah sebagai salah satu yang masuk akal untuk memecahkan.

\section{Epistemologi konsep Archimedes}

Epistemologi atau teori pengetahuan ialah cabang filsafat yang berurusan dengan hakikat dan lingkup pengetahuan, pengendalaian-pengendalian, dan dasardasarnya serta pengertian mengenai pengetahuan yang dimiliki mula-mula manusia percaya bahwa dengan kekuatan pengenalanya ia dapat mencapai realitas sebagaimana adanya (Endraswara, 2015). Epistemologi dapat didefenisikan juga sebagai cabang filsafat yang mempelajari asal mula atau sumber, struktur, metode dan sahnya (validitas) pengetahuan. Epistemologi sebagai subbidang filsafat yang bersangkutan dengan 
pengetahuan, khususnya apa yang kita tahu dan bagaimana kita tahu itu. Hofer dan Pintrich (1997) menyebut ulasan ini dua dimensi sebagai sifat pengetahuan (Percaya apa pengetahuan) dan sifat atau proses mengetahui (bagaimana seseorang untuk tahu). Ulasan Dimensi ini mewakili referensi dalam megoreksi pengetahuan fisika dan metode untuk penciptaan dan validasi.

Lebe (2015) Persoalan-persoalan dalam epistemologi hukum archimedes adalah:

1) Apakah hukum archimedes itu ?

2) Bagaimanakah Archimedes dapat menemukan hukum Archimedes?

3) Bagaimanakah validitas Hukum Archimedes itu dapat dinilai ?

Langkah dalam epistemologi hukum Archimedes antara lain berpikir deduktif dan induktif. Berpikir deduktif memberikan sifat yang rasional kepada pengetahuan ilmiah dan bersifat konsisten dengan pengetahuan yang telah dikumpulkan sebelumnya. Secara sistematik dan kumulatif pengetahuan inilah yang disusun setahap demi setahap dengan menyusun argumentasi mengenai sesuatu yang baru berdasarkan pengetahuan yang telah ada. Secara konsisten dan koheren maka ilmu mencoba memberikan penjelasan yang rasional kepada objek yang berada dalam fokus penelaahan.

Berikut akan dijawab keempat pertanyaan diatas, sehingga dasar epistimologi hukum Archimedes dapat ditunjukkan secara jelas:

1) Hukum Archimedes adalah hukum yang membahas tentang perilaku suatu benda yang mengalami gaya ketas ketika berada dalam suatu fluida.

Berdasarkan kisah yang diabadikan sejarah fisika. (Tugas archimedes pada waktu itu adalah menentukan apakah sebuah mahkota dibuat dari emas murni atau tidak. Berat mahkota tersebut sama dengan berat emas yang telah disediakan sebelumnya. la mau mengukur kandungan emas di dalam mahkota tersbut untuk mengukur kandungan emas di dalamnya. Dengan memperhatikan jumlah air yang keluar dari bak mandi setelah ia masuk kedalam bak tersebut, ia telah menemukan metode yang sederhana untuk megukur berat dirinya sendiri. Metode yang sama dapat digunakan untuk mengukur kandungan emas di dalam mahkota)

2) Untuk validitas hukum Archimedes dapat dilakukan dengan prinsip konfirmasi dengan penjelasan lengkap sebagai berikut: Fungsi IImu adalah untuk menjelaskan, memprediksi proses dan produk yang akan datang atau memberikan pemaknaan. Pemaknaan tersebut dapat ditampilkan sebagai konfirmasi absolute dengan menggunakan landasan : asumsi, postulat atau axioma yang sudah dipastikan benar. Pemaknaan juga dapat ditampilkan sebagai konfirmasi probabiliti dengan menggunakan metode induktif, deduktif, reflektif. Dalam Ontologi dikenal pembuktian priori dan posteriori.

Untuk memastikan kebenaran penjelasan atau kebenaran prediksi Archimedes, dapat didasarkan pada dua aspek yaitu Aspek kuantitatif dan aspek kualitatif. Dalam hal konfirmasi, sampai saat ini dikenal ada tiga teori konfirmasi, yaitu :

1. Decision Theory

Teori ini menerapkan kepastian berdasar keputusan apakah hubungan antara hipotesis dengan evidensi memang memiliki manfaat actual

2. Estimation Theory

Menetapkan kepastian dengan memberi peluang benar-salah dengan menggunakan konsep probabilitas.

3. Reliability Analysis

Menetapkan kepastian dengan mencermati stabilitas evidensi (yang mungkin berubah-ubah karena kondisi atau karena hal lain) terhadap hipotesis. Hukum Archimedes telah melewati tahapan konfirmasi, dan terbukti bahwa hukum Archimedes merupakan suatu hukum yang valid dan merupakan hukum fisika dan bagian dari ilmu pengetahuan.

\section{Dasar Aksiologi}

Aksiologi merubapakan cabang filsafat ilmu yang mempertanyakan bagaimana manusia menggunakan ilmunya (Endraswara, 2015). Aksiologi ilmu terdiri dari nilai-nilai yang 
bersifat normatif dalam pemberian makna terhadap kebenaran atau kenyataan seperti yang dijumpai dalam kehidupan, yang menjelajahi berbagai kawasan, seperti kawasan sosial, kawasan simbolik ataupun fisik material. Aksiologi sebagai ilmu pengetahuan yang menyelediki hakekat nilai yang umumnya ditinjau dari sudut pandang kefilsafatan.

Aksiologi menjawab, untuk apa hukum archimedes yang berupa ilmu itu digunakan, Bagaimana kaitan antara cara penggunaan tersebut dengan kaidah-kaidah moral? Bagaimana penentuan objek yang ditelaah berdasarkan pilihan-pilihan moral? Bagaimana kaitan antara teknik prosedural yang merupakan operasionalisasi metode ilmiah dengan norma-norma moral?

Ada banyak dasar aksiologi dari hukum archimedes yang sangat bermanfaat bagi kehidupan manusia, karena tujuan diciptakannya hukum archimedes ini adalah untuk memberikan manfaat dan kemudahan dalam kehidupan manusia. Beberapa diantara aplikasi hukum archimedes yang mempermudah manusia antara lain: pembuatan kapal selam dan kapal laut. Kesemuanya itu merupakan nilai aksiologi hukum archimedes. Hukum archimedes bukan hanya sebua teori kontekstual namun memiliki banyak nilai aplikatif yang menjadikan alasan yang kuat bahwa pernyataan archimedes merupakan suatu hukum dan bagian dari ilmu penegetahuan yang telah terbukti secara empiris.

Archimedes , memiliki tiga tujuan mendasar: untuk lebih integrasi sejarah ilmu pengetahuan dan teknologi dengan satu sama lain; untuk menyelidiki sejarah teknis, sosial dan praktis dari perkembangan tertentu dalam ilmu pengetahuan dan teknologi; dan akhirnya, membawa sejarah ilmu pengetahuan dan teknologi ke dalam filsafat ilmu. Secara keseluruhan, Archimedes akan menarik bagi sejarawan, filsuf, dan ilmuwan, serta orangorang dalam bisnis dan industri yang berusaha untuk memahami bagaimana ilmu pengetahuan dan industri.

\section{Implikasi dalam Pembelajaran Fisika}

Aliran filsafat yang mempengaruhi konsep Archimedes adalah aliran filsafat realisme dan empirisme. Karena itu dalam pelaksanaan pembelajaran fisika yang berkaitan dengan materi hukum Archimedes tentunya melalui pendekatan realistis dan pendektan empiris. Adapun implikasi dalam pembelajaran fisika adalah sebagai berikut:

1. Metode pembelajaran yang sesuai adalah metode ekperimen atau demonstrasi.

2. Guru hanya sebagai pembimbing saat proses pembelajaran berlangsung

3. Sumber pengetahuan/informasi dalam mempelajari hukum Archimedes adalah "pengalaman" siswa serta dibuktikan melaui ekperimen secara langsung oleh mereka sendiri.

4. Buku sumber hanya sebagai pendukung dari hasil percobaan yang siswa buktikan, artinya ada pembuktian secara real oleh siswa.

5. Pembelajaran fisika berlangsung secara aktif oleh aktifitas siswa dan siswa diberikan keempatan seluas-luasnya.

\section{Manfaat pengajaran fisika dengan Filsafat Sains}

Terdapat keutungan atau manfaat dalam mengajarkan filsafat sains sebagai berikut:

a. Menciptakan kebiasaan menganalisis segala sesuatu dalam hidup seperti yang diajarkan dalam metode berfilsafat, akan menjadikan seseorang cerdas, kritis, sistematis, dan objektif dalam melihat dan memecahkan masalah dalah kehidupan sehari-hari

b. Melatih peserta didik untuk mampu meningkatkan kualitas berfikir secara mandiri, mampu membangun pribadi yang berkarakter.

c. Memberikan dasar-dasar semua bidang kajian pengetahuan, memberikan pandangan yang sintesis atau pemahaman atas hakikat kesatuan semua pengetahuan dan kehidupan manusia lebih dipimpin oleh pengetahuan yang baik.

d. Menemukan kebenaran tentang segala sesuatu dengan menggunakan pemikiran secara serius. Belajar filsafat merupakan salah satu bentuk latihan untuk memperoleh kemampuan memecahkan 
masalah, menemukan akar persoalan yang terdalam, menemukan sebab dari suatu permasalah.

\section{PENUTUP}

Pengajaran fisika tidak hanya tentang peningkatan hasil belajar fisika akan tetapi lebih menenkankan pada bagaimana konsep pengetahuan fisika terbentuk, proses pengetahuan dialami oleh peserta didik dan aplikasi berdasarkan nilai moral sebagai pencapaian dalam pendidikan karakter. Melalui pengajaran fisika dengan memperkenalkan sejarah dan filsafat sains dapat menjembatani pengetahuan dan mengkonstruk pengetahuan tentang konsep fisika.

\section{UCAPAN TERIMAKASIH}

Ucapan terimakasih ditujukan kepada bapak Dr. Harry Firman, M.Pd sebagai pembimbing dalam membantu mengoreksi dan memberikan saran perbaikn dalam menyelesaikan artikel filsafat ilmu.

\section{DAFTAR PUSTAKA}

Crouch, C. H., Fagen, A. P., Callan, J. P., \& Mazur, E. (2004). Classroom demonstrations: Learning tools or entertainment? American Journal of Physics, 72(6), $835-838$.

DeHaan, R. L. (2005). The impending revolution in undergraduate science education. Journal of Science Education and Technology, 14 (2), $253-269$.

Endraswara, S. (2015). Filsafat IImu (Edisi Revisi). CAPS : Yogyakarta.

Hake, R. (2002). Lessons from the physics education reform effort. Conservation Ecology, 5(2), 28.

Hofer, B. K., \& Pintrich, P. R. (1997). The development of epistemological theories: Beliefs about knowledge and knowing and their relation to learning. Review of educational research, 67(1), 88-140.

Lebe, E. (2015). Aliran Filsafat yang Mempengaruhi Konsep Fisika (Mekanika).
Diakses melalui http://eduarduslebe.blogspot.co.id/

Matthews, M. R. (1994). Science teaching: The role of history and philosophy of science. Psychology Press.

Matthews, M. R. (1997). Philosophy and constructivism in science education (Special Issue).

Sin, C. (2013). Epistemology, Sociology, and Learning and Teaching in Physics. Science Education: Wiley Online Library.

Suriasumantri. S J. (2010). Filsafat IImu Sebuah Pengantar Populer. Jakarta: Pustaka Sinar Harapan.

Thacker, B.A. (2003). Recent advances in classroom physics. Reports on Progress in Physics, 66(10), 1833 - 1864.

Wattimena A, AR. (2009). Filsafat sains (Sebuah pengantar). Grasindo: Jakarta. Diakses melalui https://books.google.co.id/books. 